\title{
Religious and Spiritual Struggles as Concerns for Health and Well-Being
}

\author{
Conflitos Religiosos/Espirituais como Questões para a Saúde e o Bem-Estar
}

\begin{abstract}
Nick Stauner*
Julie J. Exline**

Kenneth I. Pargament***

Abstract

People struggle with religion and spirituality in several ways, including challenges in trusting God, confronting supernatural evil, tolerating other perspectives on religion, maintaining moral propriety, finding existential meaning, and managing religious doubt. These religious and spiritual $(\mathrm{R} / \mathrm{S})$ struggles relate to both physical and mental health independently of other religious and distress factors. Causality in this connection needs further study, but evidence supports many potential causes and moderators of the link between $\mathrm{R} / \mathrm{S}$ struggle and health. These include personality, social, and environmental influences, including traumatic experiences and subcultural differences. Many theoretical questions remain unresolved, including how change in $\mathrm{R} / \mathrm{S}$ struggle can predict or be predicted by change in health and other connected constructs, and how one might intervene to aid those who struggle with religious or spiritual challenges. Nonetheless, research momentum has grown, having already produced a wealth of information that underscores the need for greater attention to this domain. $\mathrm{R} / \mathrm{S}$ struggle poses an important exception to generally positive overall associations between religion and well-being, though even R/S struggle may promote growth. This review offers a brief introduction to emerging psychological theory and research on R/S struggle with an emphasis on its relevance to wellness and illness.
\end{abstract}

Keywords: religion; spirituality; struggle; stress; well-being; health

\section{Resumo}

As pessoas experimentam conflitos com a religião e a espiritualidade de vários modos, incluindo os desafios em confiar em Deus, o confronto com o mal sobrenatural, a tolerância em relação a outras perspectivas sobre a religião, a manutenção do decoro moral, a busca de um sentido existencial e o gerenciamento da dúvida religiosa. Esses conflitos religiosos e espirituais $(\mathrm{R} / \mathrm{S})$ dizem respeito tanto à saúde física quanto a mental, independentemente de outros fatores religiosos e de sofrimento. A relação de causa e efeito, neste contexto, necessita de mais estudos, mas há evidências que apoiam a existência de muitas causas potenciais e moderadoras da relação entre conflitos Religiosos/Espirituais (R/S) e saúde. Estas incluem personalidade, influências sociais e ambientais, incluindo as experiências traumáticas e diferenças culturais. Várias questões teóricas permanecem pendentes, incluindo como a mudança nos conflitos religiosos e espirituais (R/S) poderia prever ou ser prognóstico de mudança na saúde e outras questões afins, e como se pode intervir para ajudar aqueles que enfrentam conflitos religiosos ou espirituais. No entanto, embora o montante da pesquisa tenha crescido, tendo produzindo inclusive uma riqueza de informações, ressalta-se a necessidade de uma maior atenção nesse campo Os conflitos religiosos/espirituais ( $R / S$ ) colocam uma importante questão para a associação geralmente positiva entre religião e bem estar, ainda que os conflitos religiosos/espirituais $(R / S)$ possam promover crescimento. Esse estudo oferece uma breve introdução sobre o nascimento dessa teoria psicológica e a pesquisa sobre conflitos religiosos/espirituais (R/S), enfatizando sua relevância em relação ao bemestar e à doença.

Palavras-chave: religião; espiritualidade; luta; estresse; bem-estar; saúde.

Article received on November 10, 2015 and approved on March 24, 2016.

"Ph.D. in Psichology, Case Western Reserve University. Expertise in Quantitative Psychology, Personality Psychology, Positive Psychology. Country of Origin: United States of America. E-mail: nickstauner@gmail.com

** Ph.D. in Clinical Psychology from the State University of New York at Stony Brook, Professor in the Department of Psychological Sciences at Case Western Reserve University. Country of Origin: The United States of América. E-mail: julie.exline@case.edu

${ }^{* * *}$ Ph.D. Clinical-Community Psychology, Professor of clinical psychology at Bowling Green State University. Country of Origin: United States of America. E-mail: kpargam@bgsu.edu

Horizonte, Belo Horizonte, v. 14, n. 41, p. 48-75, Jan./Mar. 2016 - ISSN 2175-5841 


\section{Introduction}

Religious/spiritual (R/S) struggles present very rich and novel opportunities for research and theoretical development. Research and theory on R/S struggle are now blossoming into a full-fledged domain of health psychology, which poses a challenge for those who wish to keep pace. We offer a brief overview of this topic and invite interested readers to delve further into our references and other recent reviews (EXLINE, 2013; EXLINE, ROSE, 2005, 2013; MURRAY-SWANK, 2013; PARGAMENT, 2007; PARGAMENT et al., 2005).

People who struggle with religion or spirituality can often identify and describe these struggles clearly. One USA undergraduate we surveyed in 2014 offered this case:

Around the time I turned 13, I started to struggle with some types of sin, mostly relating to sex, that were very discouraging and depressing for me. I had a very difficult time overcoming these sins and making any headway in my walk with the Lord. I would often lay in bed late at night, crying and asking for God's forgiveness.

This example illustrates the potential of religious struggles to cause serious distress. Yet another case suggests a different relationship between R/S struggle and well-being: "I got extremely depressed when I was 12. Long story short, I believed that God was telling me to become a missionary in India.”

The ambiguity of this example implies that a dramatic reorientation of lifestyle toward religion could cause, result from, or otherwise accompany distress. Either struggle could build character, but struggles can also become chronic or lead to other difficulties.

Despite their relative obscurity in clinical literature, R/S struggles are not rare. More than a fourth of one large undergraduate sample reported R/S struggles (JOHNSON, HAYES, 2003). Half of an internet community sample reported negative feelings toward God due to God's perceived role in negative events 
(EXLINE, GRUBBS, 2011). The 1988 General Social Survey (GSS) revealed that $62 \%$ of a representative US sample reported sometimes feeling angry at God (EXLINE et al., 2011). Within a sample of people with chronic illnesses, 48\% reported religious struggles (FITCHETT et al., 2004). R/S struggles appear in devotees to many major religions, including Christians, Jews (e.g., ROSMARIN, PARGAMENT, FLANNELLY, 2009), Muslims (e.g., ABU-RAIYA et al., 2008), Buddhists (PHILLIPS et al., 2009), and Hindus (TARAKESHWAR et al., 2003), as well as the nonreligious (TOUSSAINT, WILLIAMS, 2008) and nonspiritual (STAUNER et al., 2015a). A study of Muslims revealed that prevalences for R/S struggles ranged from 1-40\% depending on the kind of struggle in question (ABURAIYA, PARGAMENT, EXLINE, AGBARIA, in press).

In many cultures, people may experience discomfort when discussing religion or spirituality openly. These topics often hold deep personal significance, but they invite controversy and can create inner turmoil. Many religions directly address fundamental concerns such as conflict with other people, clashes with supernatural evil, and the struggle for the approval of a higher power by resisting immoral impulses or doubts about doctrine. Yet the sensitivity of R/S topics casts even these expected R/S challenges further into shadow, leaving many to suffer in silent isolation. Some may be unable to find help outside their own religious communities, though these communities can also create or exacerbate problems in some cases. These social challenges can extend to psychologists and other health caregivers, many of whom may know little about the R/S aspects of their patients' troubles or how to manage them.

Many studies show that R/S struggles relate negatively to health and wellbeing. Scholars have gathered much evidence of the connection between health and R/S struggles through original research, reviews (e.g., ABU-RAIYA et al., 2010; EXLINE, 2013; EXLINE, ROSE, 2013; PARGAMENT, 2007) and meta-analyses (ANO, VASCONCELLES, 2005). Yet this negative link goes against the grain of dominant themes in the psychological intersection of religion and well-being, 
which mostly describe positive relationships. Religion supports well-being through many channels, as by providing and protecting existential meaning (PARK, 2013), social bonds and attachment figures (e.g., GRANQVIST, KIRKPATRICK, 2013), coping methods (PARGAMENT, 1997), and self-control (MCCULLOUGH, WILLOUGHBY, 2009), and by aiding therapy (SPERRY, MILLER, 2011).

This review will introduce several kinds of exceptions to health's positive association with religion and spirituality. The scope will include risk factors that may cause, result from, or interact with $\mathrm{R} / \mathrm{S}$ struggle, as well as implications for future work.

\section{Trauma and Illness}

$\mathrm{R} / \mathrm{S}$ struggles can develop in many ways alongside life's other complications. Many religions inherently promote concern for unguaranteed spiritual salvation through securing a higher power's forgiveness or approval, resisting evil influences and immoral compulsions, or adhering faithfully to complex systems of belief and behavioral rules. These challenges become harder to manage when life circumstances present other stressors, prompting more R/S struggle (ANO, PARGAMENT, 2013). For example, intensity of childhood physical and sexual abuse can predict greater R/S struggle (GANJE-FLING, MCCARTHY, 1996), particularly when perpetrated by clergy (BENYEI, 2014). Such trauma may disrupt victims' trust in both their religious leaders and in God, thereby undermining spiritual, relational, and emotional health (PARGAMENT et al., 2008; WOLFE et al., 2006). Abuse may also alienate victims from their religious communities if social taboos suppress open discussion of these traumas. Effects of trauma on R/S struggle occur mostly through more direct effects on posttraumatic stress (BRADLEY et al., 2005).

Evidence linking physical and psychological health to R/S struggle suggests that secondary struggles may arise as a coping response to health problems in 
general. Accordingly, theory frames some R/S struggles as negative religious coping responses (NRC; PARGAMENT et al., 1998), such as blaming God, the devil, or one's own sins for health problems, or interpreting problems as divine punishment or disproof of a benevolent God. NRC relates to (and may result from) concurrent emotional distress and psychosomatic and physical symptoms in college students. In hospital populations, NRC relates to more medical diagnoses, functional disabilities, and depression, and also relates to poorer cognitive functioning, subjective health, and quality of life (PARGAMENT et al., 1998). Longitudinal evidence also supports the potential for primary struggles to precede and cause depression rather than result from it (PIRUTINSKY et al., 2011).

Where R/S struggles manifest, whether as causes or results of these health problems, they also predict poorer prognoses for the associated health conditions and more difficulty coping with them. For example, adolescent psychiatric patients who report loss of faith suffer deeper depression and recover from it more slowly (DEW et al., 2010). In the geriatric clinical population, NRC predicts greater depression independently of patients' number of depressed episodes or amount of social support (BOSWORTH et al., 2003) and greater mortality risk over two years independently of several demographic, physical, and mental health factors (PARGAMENT et al., 2001). NRC relates to anxiety as well, especially for people who have been seriously sick or hurt recently (MCCONNELL et al., 2006). In a sample of disabled Iranian veterans, NRC predicted posttraumatic stress and psychiatric impairment independently of perceived physical health (AFLAKSEIR, COLEMAN, 2009). A sample of schizophrenia patients reported more practical burdens associated with their illness when they also reported more NRC, after controlling for severity of schizophrenic symptoms (DUARTE, 2009). In another clinical sample, appraising schizophrenia or bipolar disorder as punishment from God related to greater distress and personal losses due to mental illness (PHILLIPS, STEIN, 2007). Cancer patients who reported anger at God tended to experience more interference due to their illness and poorer adjustment in general, which worsened further over time unless their anger resolved (EXLINE et al., 
2011). Medical rehabilitation patients who felt angry at God recovered their physical independence more slowly over time (FITCHETT et al., 1999).

\section{Personal and Subcultural Risks}

It appears that people with a more negative orientation to relationships, themselves, and life generally report more R/S struggles. For instance, people with insecure attachment styles express more insecurity and disappointment in their relationships with God (HALL, EDWARDS, 2002). Of course, this differs from having no attachment to God, which may explain the relative absence of such struggles among nonbelievers (STAUNER et al., 2015a). Neuroticism also predicts R/S struggle independently of insecure attachment (ANO, PARGAMENT, 2013). This pattern generalizes to related constructs: negative affect, pessimism, depression, anxiety, paranoid ideation, hostility, and obsessive-compulsiveness also predict NRC (SCHOTTENBAUER et al., 2006; MCCONNELL et al., 2006; FITCHETT et al., 2004). Low self-rated confidence, competence, esteem, liking, fitness, and body image (independent of BMI; KIM, 2006) relate to more negative attitudes toward God as well (GREENWAY, MILNE, CLARKE, 2003).

More subtly related personality constructs may also affect susceptibility to R/S struggle. Entitlement predicts more anger at God independently of neuroticism and trait anger (GRUBBS, EXLINE, CAMPBELL, 2013). Spiritual entitlement may lead to unrealistic expectations from God and anger or disappointment when such expectations go unfulfilled (GRUBBS, EXLINE, CAMPBELL, TWENGE, PARGAMENT, in preparation), as may narcissism, a similar trait (HALL, EDWARDS, 2002).

Narcissism may also manifest as unrealistic standards for spiritual or moral purity among people of particularly scrupulous faith traditions (SHULTS, SANDAGE, 2006). Holding oneself to excessively stringent standards of behavior 
may enable a narcissistic sense of moral superiority, but when one fails to uphold these standards, moral struggles such as R/S guilt or shame may result. The shattered sense of superiority may exacerbate these struggles among those with the more fragile style of narcissism (SANDAGE, MOE, 2011).

Aspects of some religious subcultures may play independent roles in cycles of religious striving and shame. Mainstream religion generally promotes moral awareness and may prevent immoral behavior (MCCULLOUGH, WILLOUGHBY, 2009), but R/S cults at the extreme fringe of scrupulousness may promote moral struggles by placing very intense demands on their members. Spiritual abuse, the use of religious authority to convince people of their inherent guilt and impending spiritual doom (especially for manipulative rather than compassionate purposes), may feature prominently in the dynamics of cults that place particularly unhealthy emphasis on the necessity of strict religious observance and heavy tribute and sacrifice to avoid damnation (PURCELL, 2008). When those suffering extraordinary spiritual shame see further investment in the costly display of religious commitment as their only opportunity for relief and salvation, a form of addiction to religion may result, mimicking the symptoms and consequences of obsessive-compulsive disorders (TAYLOR, 2002).

People who develop an addiction to religion may not recognize this as a problem, but religious addiction may still disrupt their personal, social, and professional lives. Subjectively recognizable R/S struggles such as fears of God and sin emerge in proportion to obsessive belief characteristics, which vary across both individuals and cultures (INOZU et al., 2012). In exceptionally pathological situations, cult leaders may cultivate dependence on the internal authority structure by framing their followers' preexisting support networks as channels of immoral or demonic influence. This introverted social pressure to submit to and depend on a cult leader, when combined with externalized pressure to reject outside influence, may generate an inward spiral of obsessive motives in cultists, whose personalities may change rapidly and drastically (CONWAY, SIEGELMAN, 
1995). The worst health risks of destabilizing cult influences can result in the loss of lives to extreme stress, deprivation, and violence.

\section{Taxonomic Structure of R/S Struggles}

In empirical terms, drawing distinctions among the various types of $\mathrm{R} / \mathrm{S}$ struggles adds explanatory and predictive value. Struggles with God, other people, and religious doubt each predict psychological distress independently (ELLISON, LEE, 2010). In one clinical sample, alienation from God predicted depression much better than interpersonal struggle or religious fear and guilt, though fear and guilt predicted suicidality best (EXLINE, YALI, SANDERSON, 2000). In a large university sample, religiousness best predicted struggle with supernatural evil (EXLINE et al., 2014), whereas neuroticism best predicted ultimate meaning struggle, and lifetime trauma best predicted interpersonal R/S struggle (STAUNER et al., 2015c). When used as predictors, ultimate meaning struggle best predicted low well-being, whereas an independent, positive relationship with well-being emerged for religious doubt struggle when controlling other R/S struggles (STAUNER et al., 2015b).

This empirical evidence compels a closer look at discrete types of R/S struggle. Our coverage will follow the six-factor structure proposed by Exline and colleagues (2014), which categorizes R/S struggles as divine, demonic, interpersonal, moral, ultimate meaning, or doubt struggles. Only divine and demonic struggles necessarily entail supernatural belief, though these may concern the nonreligious, nonspiritual, and some nonbelievers nonetheless (STAUNER et al., 2015a; TOUSSAINT, WILLIAMS, 2008). Pargament (2007) has further differentiated interpersonal and intrapersonal (i.e., moral, meaning, and doubt) struggles. 


\subsection{Divine struggle}

Divine struggles comprise some of the most-researched varieties of $\mathrm{R} / \mathrm{S}$ struggle. These struggles include anger at God and other negative or ambivalent emotions (BECK, 2006), such as feelings of God's disapproval, punishment, or abandonment. These problems may arise from personal actions in the same way as moral struggles (GRUBBS, EXLINE, 2014), or from more existential, religious, or spiritual sources such as non-benevolent theodicies (WILT, EXLINE, PARK, PARGAMENT, in press) including views of God as cruel or distant (EXLINE, GRUBBS, HOMOLKA, 2015).

People often feel uncomfortable admitting their own divine struggles. Religious groups differ both in the amount of divine struggle they report and in the degree to which they see anger at God as morally acceptable (EXLINE, KAPLAN, GRUBBS, 2012). Muslims may particularly resist expressions of anger at God (ABU-RAIYA et al.). Some nonbelievers also report a past history of anger at God or anger focused on a hypothetical image of God (BRADLEY et al., 2015; EXLINE et al., 2011). Nonreligious people also feel less forgiven by God than Christians do (TOUSSAINT, WILLIAMS, 2008).

Some argue that negativity toward God need not threaten one's relationship with God (EXLINE et al., 2012). However, when people disclose their anger at God to others, unsupportive or judgmental responses predict difficulty resolving the anger at God (EXLINE, GRUBBS, 2011). Most evidence indicates that negative attitudes toward God relate to poorer well-being and health behaviors concurrently and worsening health over time (FITCHETT et al., 1999, 2004; GREENWAY et al., 2003; EXLINE, 2013). Negative attitudes with known health relationships include fear of abandonment by God (HALL, EDWARDS, 2002; PARGAMENT et al., 2001), feeling unforgiven by God (TOUSSAINT et al., 2008; MARTIN, 2008), interpretation of negative events as divine punishment (PARGAMENT, KOENIG, PEREZ, 2000), and impersonal or hostile God images (BENSON, SPILKA, 1973). 


\subsection{Demonic struggle}

Some supernatural forces are hostile by definition. People who perceive demonic influence in their lives find this troubling almost unanimously. Despite popular belief in the devil, relatively little empirical literature addresses the phenomenology of demonic struggle (KRUMREI et al., 2011; EXLINE, ROSE, 2005, 2013). This neglect may result from scientists' dismissal of the topic as a matter of religion; in fairness, demonic struggle correlates strongly with religiousness (EXLINE et al., 2014). Researchers may also conflate demonic struggle with nonreligious psychosis or hallucinations, such as those caused by sleep paralysis (CHEYNE, 2003).

In some cases, the line between demonic struggle and mental illness can blur (PECK, 2005). Many bestselling Christian self-help books blur the line further; a content analysis identified demonic influence as the most frequent explanation of depression in 14 of these books, exceeding physiological causes and negative cognitions, emotions, and self-images (WEBB, STETZ, HEDDEN, 2008). Similar confusion over the sources of depression, schizophrenia, epilepsy (BAXENDALE, 2008), dissociative identity disorder, and other maladies exists in many religious cultures, including Christianity (HARLEY, 2007; HARTOG, GOW, 2005), Islam (EID, ALZAYED, 2005), Hinduism (BROCKMAN, 2000), and Buddhism (PLAKUN, 2008). Those suffering from disorders with concomitant demonic struggle may prefer spiritual healers over clinicians (CHIU, 2000), further obscuring demonic struggles from the medical community's awareness. Traditional Western views sometimes blame demonic struggles on spiritual weakness or receptivity to evil influence, leaving those wrestling with their demons few in whom to confide.

Despite the scarcity of empirical research, demonic struggles are not rare. A large study of Christian church members observed a wide range of prevalences across denominations, from 11\% (Congregationalists) to $76 \%$ (Southern Baptists; 
STARK, 1965). In a sample of ten mothers of drowned Bangladeshi children, seven attributed their losses to supernatural evil (BLUM et al., 2009). In a sample of 100 recent divorcees, 48 reported some demonic struggle (KRUMREI et al., 2011), which suggests a prevalence rate similar to other R/S struggles.

Associations vary between demonic struggle and indicators of psychological adjustment. Krumrei and colleagues (2011) found that demonic struggle correlated positively with posttraumatic stress, depression, anger, and NRC with divorce. However, it also correlated positively with positive spiritual emotions about divorce, possibly due to defensive bonding with God, transferring guilt away from oneself or God (BECK, TAYLOR, 2008), or stress-induced spiritual growth. Among college students, demonic reappraisal of past trauma associated positively with reports of spiritual growth and growing closer to God and the church (PARGAMENT et al., 2000). Still, attributing problems to the devil predicted increased mortality risk among an elderly hospital sample after controlling demographic, physical, and mental health factors (PARGAMENT et al., 2001). Belief in an active Satan may also link to interpersonal conflict through prejudice against homosexuality (WILSON, HUFF, 2001), which some attribute to demonic influence directly (VAN KLINKEN, 2013).

\subsection{Interpersonal struggle}

Of the major types of R/S struggles, interpersonal struggle may take the widest variety of forms. Like divine and demonic struggles, conflicts with both one's ingroup and outgroups may prompt R/S struggle when they involve religion's manifestations in the natural world.

Discrimination and conflict involving religious groups cause some interpersonal R/S struggles. The perception that God has forbidden a behavior or rejected another group, or that demonic influences have acted through a person or group may motivate discrimination. Secular issues may also generate 
discrimination against religious groups, such as the association of Islam with terrorism (ABU-RAS, SUÁREZ, 2009), wars in Western and Southern Asia (ABURAS, HOSEIN, 2015), and immigration issues in Europe that the ongoing Syrian refugee crisis has exacerbated. Violent religious discrimination often mimics, mixes with, causes, or results from racism, especially when its targets belong to an ethnic minority (e.g., 310 cases of arson against African American churches from 19952000; GERSTENFELD, 2013). Ethnic features of victimized minorities may differ more subtly than skin color; for example, sectarian prejudice impairs the social and economic well-being of Irish Catholics in parts of the UK (WALLS, WILLIAMS, 2004).

Similarly subtle discrimination persists against atheists (GERVAIS et al., 2011), who face particularly pervasive prejudice worldwide, even absent any ethnic differences or information (e.g., when presented as imaginary targets), and even in predominantly nonreligious regions like Scandinavia (GERVAIS, 2015). Discrimination against atheists manifests in many overt ways as well, including slander and ostracism (HAMMER, CRAGUN, SMITH, 2012). In at least 13 countries, atheists, apostates, or blasphemers face legal consequences as severe as the death penalty (IHEU, 2014). Even absent such deliberately harmful policies, discrimination relates negatively to atheists' self-esteem, life satisfaction, and physical health (DOANE, ELLIOTT, 2015).

As a form of intergroup struggle, discrimination afflicts the discriminator as well. Anger toward religious groups may incite conflict or crime, worsening the discriminator's own life in the process . Some use religious beliefs to justify or even sanctify violence (BUSHMAN et al., 2006). Victims may also become prejudiced against an aggressor's group, threatening the innocence and safety of all people associated, even if these innocents only associate indirectly as through ethnicity and not through religion (e.g., Arab-American Christians; ABU-RAS, ABUBADER, 2009). 
Interpersonal struggle may arise by similar means within religious groups (e.g., ELLISON et al., 2009). People may disagree with changes in their religious leadership's policies, such as those surrounding the ordination of female ministers or tolerance of homosexuality in Christianity, or they may face such discrimination themselves. Discrimination aside, innumerable other bases for interpersonal conflict exist within religious organizations, as in all organizations. Still, the confluence of conflicts between tradition and modernism, fundamentalism and liberalism, and supernaturalism and secularism imbue organizational conflicts with uniqueness in religious contexts. Individual differences in these values can arise naturally, even among siblings raised into the same faith, so it would seem that no one religious sect can fit all individuals mutually without tension. This dissonance can disrupt the socially supportive function of religious groups, which may partly explain the negative health correlates of interpersonal R/S struggles (KRAUSE, WULFF, 2005).

Particularly harmful causes of interpersonal struggle include abuse of power in religious organizations. Spiritual abuse by religious authorities, including parents, assaults one's emotions, sense of security and self-worth, and it can undermine the religious organization as a source of comfort, support, and identity (PURCELL, 2008). When abuse includes physical or sexual elements, devastating trauma can result, potentially including psychiatric illness (PARGAMENT et al., 2008; WOLFE et al., 2006). Even when sexual abuse comes from outside one's religious power structure, it may inadvertently alienate people from their religious communities if taboos about nontraditional sexuality suppress discussion of rape and molestation. Social suppression may do even more damage when abuse occurs within the organization (BENYEI, 2014). Tragically, this censorship also reinforces victims' self-blame, which constitutes another form of R/S struggle in itself. 


\subsection{Moral struggle}

Sexual abuse by clergy can unite victim and perpetrator in a common moral struggle. Victims often blame themselves in even the most innocent circumstances. Perpetrators must also cope with their wrongdoings to some degree, which might include defensive responses such as repression (PLANTE, ALDRIDGE, 2005). Strong correlations with other struggles (EXLINE et al., 2014) suggest that moral struggles may pose an enhanced risk of generating other R/S struggles, such as religious fear and guilt (EXLINE, YALI, SANDERSON, 2000; PARGAMENT et al., 1998), demonic attributions for one's moral shortcomings (BLUM et al., 2009), or strained relationships with one's religious community or family (ALTEMEYER, HUNSBERGER, 1997).

A theoretical distinction between moral struggles and struggles with God, demons, and people begins here: individuals experience moral struggles within themselves, rather than in their relationships with others (whether human or supernatural). This degree of independence grants moral struggles the potential to manifest through one's private actions, regardless of supernatural belief. Though this independence from supernatural belief might seem to imply a greater vulnerability to moral struggles among the nonreligious relative to other struggles, no such difference manifests in distributions of struggles according to current evidence. Instead, religious people report more moral struggles than nonreligious people, who collectively report levels of moral struggle similar to their levels of supernatural and interpersonal struggles (STAUNER et al., 2015a). The greater moral struggles among religious people may reflect tendencies of scrupulous cultures to express more concern about sin or of guilt-prone individuals to endorse more scrupulous beliefs (INOZU et al., 2012).

As with other struggles, the inability or refusal to forgive oneself for past sins relates to more negative emotions and lower self-esteem (MAUGER et al., 1992), and it also predicts more depressive episodes (TOUSSAINT et al., 2008). These 
findings highlight the importance of self-forgiveness in those coping with moral struggle (HALL, FINCHAM, 2005). Self-forgiveness may also help people to resolve concurrent divine struggle, since self-forgiveness may support feeling forgiven by God (MARTIN, 2008).

\subsection{Ultimate meaning struggle}

The intrapersonal struggle with self-worth may also manifest as a distressing lack of existential meaning or worthwhile, coherent purpose in one's personal life or in the world at large. Rather than challenging self-worth through guilt or shame over wrongdoing, ultimate meaning struggle seems to represent the absence or insufficiency of deep personal value. In contrast with moral struggle, ultimate meaning struggle appears greater among the nonreligious (STAUNER et al., 2015a). The greater meaning struggle among the nonreligious may reflect a value gap left by the erosion of religion's popularity as a basis of existential meaning in Western culture (BAUMEISTER, 1991). A void of existential meaning may therefore reflect a religious struggle for those who expect religion to provide them meaning. In the sense of spirituality that derives transcendence from transgenerational connectedness to humanity and the universe at large (PIEDMONT, 1999), an inability to perceive meaningful connections to others or transcendent universal principles may also constitute a spiritual struggle. These definitions may explain the endorsement of ultimate meaning struggles among those lacking a religious or spiritual identification.

General meaning in life relates to a wide variety of health indicators including physical and psychological well-being and the absence of suffering, illness, and negative health outcomes (for a review, see STAUNER, 2013). A prominent theory of psychological well-being lists purpose in life as one of its six components (RYFF, 1989). Convergent results of multiple regression analyses demonstrate that ultimate meaning struggle predicts lower general meaning in life and lower life satisfaction strongly and independently of other struggles and 
religiousness (STAUNER et al., 2015b). This finding highlights the exceptional relevance of ultimate meaning struggle to health. Frankl (1946/1992) claimed that one's success in finding or preserving meaning in even the most dire and dehumanizing of circumstances can determine whether one survives the ordeal. Even in more mundane scenarios, purpose in life predicts greater longevity among the elderly (BOYLE et al., 2009).

Though meaning in life tends to increase with age (REKER, 2005), Erikson's theory of adult development suggests some normative struggle around the choice of generativity versus stagnation in old age (SLATER, 2003). Other potential threats to meaning include trauma (e.g., bereavement; DAVIS et al., 2000) and conflict with other ideologies (HEINE, PROULX, VOHS, 2006). Mitigating factors such as religious conversion may foster an increased sense of purpose, although such increases will be temporary in some cases (PALOUTZIAN, 1981). Non-R/S means of achieving a deeply fulfilling sense of horizontal transcendence (HOOD, HILL, SPILKA, 2009) or symbolic immortality also exist, such as the humanistic or philanthropic pursuit of a prosocial legacy of personal achievement or building and supporting a family (LIFTON, OLSON, 2009), but whether these offer solutions to existing struggle or protect against their emergence remains to be determined.

\subsection{Doubt struggle}

As an emerging cause of widespread struggle with ultimate meaning, Baumeister's (1991) theory of the value gap caused by widespread declines in religious affiliation directly implicates religious doubt in the origins of this gap. Struggle with R/S doubt concludes this list of major types of R/S struggle, and constitutes a third intrapersonal type of struggle. In a sense, doubt struggle applies the fear of meaninglessness directly to $\mathrm{R} / \mathrm{S}$ beliefs, from whence it may spread to life in general in those who depend on these beliefs to orient their lives. However, doubt struggle remains distinct from ultimate meaning struggle. Doubt struggle concerns specific R/S beliefs, such as whether a religious text is literally true, 
whether one has chosen the "correct" religion, or whether the teachings of one's religious group can be trusted.

Like other R/S struggles, doubt struggles associate positively with depressive symptoms and other indicators of emotional distress (EXLINE et al., 2014). However, when controlling the strong negative effect of ultimate meaning struggle and other less predictive kinds of $\mathrm{R} / \mathrm{S}$ struggle on life satisfaction in multiple regression, doubt struggle may reverse its bivariate relationship and predict life satisfaction positively (EXLINE et al., 2014; STAUNER et al., 2015b). This supports some theoretical positions that legitimize doubt as a potentially healthy element of engagement in a quest orientation to religion (BATSON, SCHOENRADE, 1991). Nonetheless, the strong relationships doubt struggle shares with other R/S struggles seem likely to confound its relationships with well-being or growth, suppressing any positive, direct ramifications of doubt, and compounding any negatives.

\section{Conclusions and Future Directions}

As shown in this review, people experience a wide variety of $\mathrm{R} / \mathrm{S}$ struggles, and these struggles show many connections with mental and physical health. However, one must also avoid overlooking the limits to causal inference present throughout the many correlational results presented here. Though ethical boundaries complicate the prospect of experimentally inducing R/S struggle, experimental and clinical interventions for struggle deserve dedicated effort. We know little about developmental trajectories in R/S struggle over short intervals, let alone the lifespan. Longitudinal research holds considerable potential to advance theory in both of these ways. Further insights on the causal mechanisms underlying the myriad associations of R/S struggle and health may lead to better opportunities

for intervention and the ultimate resolution of this particularly sensitive form of distress. 
Recent research supports hopes that spiritual and post-traumatic growth may follow struggle, given positive R/S coping in supportive social environments (DESAI, PARGAMENT, in press; for a review, see PARGAMENT, DESAI, MCCONNELL, 2006). If growth occurs, even R/S struggles could strengthen links between religion and health. Supporting this transformative process is a laudable (yet lofty) goal for research on individual differences in change patterns and for development of new interventions.

Cross-cultural research also has an important role to fill in theory on R/S struggle. While a remarkable variety of information on different religions' experiences of R/S struggle already exists, no doubt this only begins to reveal the depth of interactions between cultures and health outcomes. To fully serve the spiritual needs of an incalculably diverse global society, we must strive to build sensitivity to the complexity of differences among world religions. Compared to this array of religious differences, the diversity of R/S struggles seems quite manageable, but it is important to remember how these modest beginnings remain embedded within their cultural contexts, and thus subject to change in any other.

Despite the complications of causality, culture, and change, many principles outlined here that connect R/S struggle to health seem likely to generalize. Not all cultures share these challenges, nor must causality operate simply for one to posit that every path through life traverses its share of R/S struggle. These psychological challenges do not exist in isolation from the world; they bear serious implications for personal and communal well-being that society cannot afford to neglect. Through careful consideration and dissemination of the knowledge psychologists have compiled on $\mathrm{R} / \mathrm{S}$ struggle, we hope the work that remains needed to understand and address these fundamental challenges will become clearer to envision and clearer in its urgency. 


\section{REFERENCES}

ABU-RAIYA, H.; PARGAMENT, K. I.; EXLINE, J. J.; AGBARIA, Q. Prevalence, predictors and implications of religious/spiritual struggles among Muslims. Journal for the Scientific Study of Religion, Hoboken, NJ, in press.

ABU-RAIYA, H.; PARGAMENT, K. I.; MAGYAR-RUSSELL, G. When religion goes awry: Religious risk factors for poorer health and well-being. In VERHAGEN, P. J.; VAN PRAAG, H. M.; LOPEZ-IBOR, J. J. Jr.; COX, J. L.; MOUSSAOUI, D. (Eds.), Religion and psychiatry:. Oxford, United Kingdom: Wiley-Blackwell, 2010.

ABU-RAIYA, H.; PARGAMENT, K. I.; MAHONEY, A.; STEIN, C. A psychological measure of Islamic religiousness: Development and evidence for reliability and validity.

International Journal for the Psychology of Religion, Hillsdale, N.J., v. 18, n. 4, p. 291-315, 2008.

ABU-RAS, W.; ABU-BADER, S. The impact of September 11, 2001, attacks on the wellbeing of Arab Americans in New York City. Journal of Muslim Mental Health, Ann Arbor, v. 3, n. 2, p. 217-239, 2008.

ABU-RAS, W.; HOSEIN, S. Understanding resiliency through vulnerability: Cultural meaning and religious practice among Muslim military personnel. Psychology of Religion and Spirituality, Washington, D.C., v. 7, n. 3, p. 179-191, 2015.

ABU-RAS, W.; SUÁREZ, Z. E. Muslim men and women's perception of discrimination, hate crimes, and PTSD symptoms post-9/11. Traumatology, Athens, v. 15, n. 3, p. 48-63, 2009.

AFLAKSEIR, A.; COLEMAN, P. G. The influence of religious coping on the mental health of disabled Iranian war veterans. Mental Health, Religion and Culture, Abingdon, v. 12, n. 2, p. 175-190, 2009.

ALTEMEYER, B.; HUNSBERGER, B. Amazing conversions: Why some turn to faith and others abandon religion. Amherst, NY: Prometheus, 1997.

ANO, G. G.; PARGAMENT, K. I. Predictors of spiritual struggles: An exploratory study. Mental Health, Religion \& Culture, Abingdon, v. 16, n. 4, p. 419-434, 2013.

ANO, G. G.; VASCONCELLES, E. B. Religious coping and psychological adjustment to stress: A meta-analysis. Journal of Clinical Psychology, New York, v. 61, n. 4, p. 461480, 2005 .

BATSON, C. D.; SCHOENRADE, P. A. Measuring religion as quest: 1) Validity concerns. Journal for the Scientific Study of Religion, New Haven, v. 30, n. 4, p. 416-429, 1991.

BAUMEISTER, R. F. Meanings of Life. New York: Guilford, 1991. 
BAXENDALE, S. The intriguing case of Christina the Astonishing. Neurology, Cleveland, v. 70, n. 21, 2008, p. 2004-2007.

BECK, R. Communion and complaint: Attachment, object-relations, and triangular love perspectives on relationship with God. Journal of Psychology and Theology, La Mirada, CA, v. 34, n. 1, p. 43-52, 2006.

BECK, R.; TAYLOR, S. The emotional burden of monotheism: Satan, theodicy, and relationship with God. Journal of Psychology and Theology, La Mirada, CA, v. 36, n. 3, p. 151-16o, 2008.

BENSON, P. L.; SPILKA, B. God image as a function of self-esteem and locus of control. Journal for the Scientific Study of Religion, New Haven, v. 13, n. 3, p. 297-310, 1973.

BENYEI, C. R. Understanding clergy misconduct in religious systems: Scapegoating, family secrets, and the abuse of power. New York: Routledge, 2014.

BLUM, L. S.; KHAN, R.; HYDER, A. A.; SHAHANAJ, S.; EL ARIFEEN, S.; BAQUI, A. (2009). Childhood drowning in Matlab, Bangladesh: An in-depth exploration of community perceptions and practices. Social Science \& Medicine, Oxford, v. 68, n. 9, p. 1720-1727, 2009.

BOSWORTH, H. B.; PARK, K. S.; MCQUOID, D. R.; HAYS, J. C.; STEFFENS, D. C. The impact of religious practice and religious coping on geriatric depression. International Journal of Geriatric Psychiatry, Manchester, v. 18, n. 10, p. 905-914, 2003.

BOYLE, P. A.; BARNES, L. L.; BUCHMAN, A. S.; BENNETT, D. A. Purpose in life is associated with mortality among community-dwelling older persons. Psychosomatic Medicine, New York, v. 71, n. 5, p. 574-579, 2009.

BRADLEY, D. F.; EXLINE, J. J.; UZDAVINES, A. The god of nonbelievers: Characteristics of a hypothetical god. Science, Religion and Culture, Surrey, UK, v. 2, p. 120-130, 2015 .

BRADLEY, R.; SCHWARTZ, A. C.; KASLOW, N. J. Posttraumatic stress disorder symptoms among low-income, African American women with a history of intimate partner violence and suicidal behaviors: Self-esteem, social support, and religious coping. Journal of Traumatic Stress, New York, v. 18, n. 6, p. 685-696, 2005.

BUSHMAN, B. J.; RIDGE, R. D.; DAS, E.; KEY, C. W.; BUSATH, G. L. When God sanctions killing effect of scriptural violence on aggression. Psychological Science, Thousand Oaks, CA , v. 18, n. 3, p. 204-207, 2007.

CHEYNE, J. A. Sleep paralysis and the structure of waking-nightmare hallucinations. Dreaming, London, v. 13, n. 3, p. 163-179, 2003. 
CHIU, S. N. Historical, religious and medical perspectives of possession phenomenon. Hong Kong Journal of Psychiatry, Hong Kong, v. 10, n. 1, p. 14-18, 2000.

CONWAY, F.; SIEGELMAN, J. Snapping: America's epidemic of sudden personality change (2nd ed.). New York: Stillpoint Press, 1995.

DAVIS, C. G.; WORTMAN, C. B.; LEHMAN, D. R.; SILVER, R.C. Searching for meaning in loss: Are clinical assumptions correct? Death Studies, Philadelphia, v. 24, p. 497-540, 2000.

DESAI, K. M.; PARGAMENT, K. I. Predictors of growth and decline following spiritual struggles. International Journal for the Psychology of Religion, Hillsdale, N.J., in press.

DEW, R. E.; DANIEL, S. S.; GOLDSTON, D. B.; MCCALL, W. V.; KUCHIBHATLA, M.; SCHLEIFER, C.; TRIPLETT, M. F.; KOENIG, H. G. A prospective study of religion/spirituality and depressive symptoms among adolescent psychiatric patients. Journal of Affective Disorders, New York, v. 120, n. 1, p. 149-157, 2010.

DOANE, M. J.; ELLIOTT, M. Perceptions of discrimination among atheists: Consequences for atheist identification, psychological and physical well-being. Psychology of Religion and Spirituality, Washington, D.C, v. 7, n. 2, p. 130-141, 2015.

DUARTE, E. A. General religiosity and use of religious coping as predictors of treatment gains for patients with schizophrenia and their relatives. Open Access Dissertations, University of Miami, Scholarly Repository, Miami, Paper n. 299, August 26, 2009.

EID, S.; ALZAYED, A. Knowledge of symptoms and treatment of schizophrenia and depression among Kuwaiti population. Arab Journal of Psychiatry, Amman, v. 16, n. 1, p. 62-77, 2005.

ELLISON, C. G.; KRAUSE, N. M.; SHEPHERD, B. C.; CHAVES, M. A. Size, conflict, and opportunities for interaction: Congregational effects on members' anticipated support and negative interaction. Journal for the Scientific Study of Religion, New Haven, v. 48, p. 1-15, 2009.

ELLISON, C. G.; LEE, J. Spiritual struggles and psychological distress: Is there a dark side of religion? Social Indicators Research, [s.l.], v. 98, n. 3, p. 501-517, 2010.

EXLINE, J. J. Religious and spiritual struggles. In PARGAMENT, K. I. (Editor-in-Chief), EXLINE, J. J.; JONES, J. W. (Associate Eds.), APA handbook of psychology, religion, and spirituality. Washington, DC: American Psychological Association, 2013.

EXLINE, J. J.; GRUBBS, J. B. "If I tell others about my anger toward God, how will they respond?" Predictors, associated behaviors, and outcomes in an adult sample. Journal of Psychology \& Theology, La Mirada, v. 39, n. 4, p. 304-315, 2011. 
EXLINE, J. J.; GRUBBS, J. B.; HOMOLKA, S. J. Seeing God as cruel vs. distant: Links with divine struggles involving anger, doubt, and fear of God's disapproval. International Journal for the Psychology of Religion, Hillsdale, N.J., v. 25, p. 29-41, 2015.

EXLINE, J. J.; KAPLAN, K. J.; GRUBBS, J. B. Anger, exit, and assertion: Do people see protest toward God as morally acceptable? Psychology of Religion and Spirituality, Washington, D.C, v. 4, n. 4, p. 264-277, 2012.

EXLINE, J. J.; PARGAMENT, K. I.; GRUBBS, J. B.; YALI, A. M. The Religious and Spiritual Struggles Scale: Development and initial validation. Psychology of Religion and Spirituality, Washington, D.C, v. 6, n. 3, p. 208-222, 2014.

EXLINE, J. J.; PARK, C. L.; SMYTH, J. M.; CAREY, M. P. Anger toward God: Socialcognitive predictors, prevalence, and links with adjustment to bereavement and cancer. Journal of Personality and Social Psychology, Washington, v. 100, n. 1, p. 129-148, 2011.

EXLINE, J. J.; ROSE, E. D. Religious and spiritual struggles. In PALOUTZIAN, R. F.; PARK, C. L. (Eds.), Handbook of the psychology of religion and spirituality (2nd ed.; pp. 380-398). New York: Guilford, 2013.

EXLINE, J. J.; ROSE, E. Religious and spiritual struggles. In PALOUTZIAN, R. F.; PARK, C. L. (Eds.), Handbook of the psychology of religion. New York: Guilford, 2005.

EXLINE, J. J.; YALI, A. M.; SANDERSON, W. C. Guilt, discord, and alienation: The role of religious strain in depression and suicidality. Journal of Clinical Psychology, New York v. 56, n. 12, p. 1481-1496, 2000.

FITCHETT, G.; MURPHY, P. E.; KIM, J.; GIBBONS, J. L.; CAMERON, J. R.; DAVIS, J. A. Religious struggle: Prevalence, correlates and mental health risks in diabetic, congestive heart failure, and oncology patients. International Journal of Psychiatry in Medicine, Amityville, NY, v. 34, n. 2, p. 179-196, 2004.

FITCHETT, G.; RYBARCZYK, B. D.; DEMARCO, G. A.; NICHOLAS, J. J. The role of religion in medical rehabilitation outcomes: A longitudinal study. Rehabilitation Psychology, Washington, v. 44, n. 4, p. 1-22, 1999.

FRANKL, V. Man's search for meaning (4th ed.). Boston, MA: Beacon Press, 1992. (Original work published 1946).

GANJE-FLING, M. A.; MCCARTHY, P. Impact of childhood sexual abuse on client spiritual development: Counseling implications. Journal of Counseling \& Development, v. 74, n. 3, p. 253-258, 1996.

GERSTENFELD, P. B. Hate crimes: Causes, controls, and controversies. Los Angeles, CA: SAGE, 2013. 
GERVAIS, W. M. The Varieties of Nonreligious Experience: Causes and Consequences of Religious Disbelief. Presented at the convention for the American Psychological Association, Toronto, 2015, August.

GERVAIS, W. M.; SHARIFF, A. F.; NORENZAYAN, A. Do you believe in atheists? Distrust is central to anti-atheist prejudice. Journal of Personality and Social Psychology, Washington, v. 101, n. 6, p. 1189-1206, 2011.

GRANQVIST, P.; KIRKPATRICK, L. A. Religion, spirituality, and attachment. In PARGAMENT, K. I. (Editor-in-Chief); EXLINE, J. J.; JONES, J. W. (Associate Eds.), APA handbook of psychology, religion, and spirituality. Washington, DC: American Psychological Association, 2013.

GREENWAY, A. P.; MILNE, L. C.; CLARKE, V. Personality variables, self-esteem and depression and an individual's perception of God. Mental Health, Religion \& Culture, Abingdon, v. 6, n. 1, p. 45-58, 2003.

GRUBBS, J. B.; EXLINE, J. J. Why did God make me this way? Anger at God in the context of personal transgressions. Journal of Psychology and Theology, La Mirada, CA, v. 42, p. 315-325.

GRUBBS, J. B.; EXLINE, J. J.; CAMPBELL, W. K. I deserve better and god knows it! Psychological entitlement as a robust predictor of anger at God. Psychology of Religion and Spirituality, Washington, D.C, v. 5, n. 3, p. 192-200, 2013.

GRUBBS, J. B.; EXLINE, J. J.; CAMPBELL, W. K.; TWENGE, J. M.; PARGAMENT, K. I. God owes me! An examination of divine entitlement, divine struggle, and psychological distress. Manuscript in preparation.

HALL, J. H.; FINCHAM, F. D. Self-forgiveness: The stepchild of forgiveness research. Journal of Social and Clinical Psychology, New York, v. 24, p. 621-637, 2005.

HAMMER, J. H.; CRAGUN, R. T.; HWANG, K.; SMITH, J. M. Forms, frequency, and correlates of perceived anti-atheist discrimination. Secularism and Nonreligion, Tampa, v. 1, p. 43-67, 2012.

HARLEY, J. L. Pentecostal Christian view toward causes and treatment of mental health disorders. Unpublished doctoral dissertation, Regent University, 2007.

HARTOG, K.; GOW, K. M. Religious attributions pertaining to the causes and cures of mental illness. Mental Health, Religion and Culture, Abingdon ,v. 8, p. 263-276, 2005 .

HEINE, S. J.; PROULX, T.; VOHS, K. D. The meaning maintenance model: On the coherence of social motivations. Personality and Social Psychology Review, Mahwah, v. 10, n. 2, p. 88-110, 2006. 
HOOD, R. W.; HILL, P. C.; SPILKA, B. The psychology of religion: An empirical approach (4th ed.). New York: Guilford Press, 2009.

INTERNATIONAL HUMANIST AND ETHICAL UNION - IHEU. Freedom of thought 2014: A global report on the rights, legal status, and discrimination against humanists, atheists, and the non-religious. Available at:

<file://C:/Users/101045/Downloads/FOT2014\%20Full\%2020141210.pdf>. Accessed on: October 29, 2015.

INOZU, M.; CLARK, D. A.; KARANCI, A. N. Scrupulosity in Islam: A comparison of highly religious Turkish and Canadian samples. Behavior Therapy, New York, v. 43, n. 1, p. 190-202, 2012.

JOHNSON, C. V.; HAYES, J. A. Troubled spirits: Prevalence and predictors of religious and spiritual concerns among university students and counseling center clients. Journal of Counseling Psychology, Tempe, v. 50, n. 4, p. 409-419, 2003.

KIM, K. H. Religion, body satisfaction, and dieting. Appetite, London, v. 46, n. 3, p. 285296, 2006.

KRAUSE, N.; WULFF, K. H. Church-based social ties, a sense of belonging in a congregation, and physical health status. International Journal for the Psychology of Religion, Hillsdale, N.J. v. 15, n. 1, p. 73-93, 2005.

KRUMREI, E. J., MAHONEY, A.; PARGAMENT, K. I. Demonization of Divorce: Prevalence Rates and Links to Postdivorce Adjustment. Family Relations, Bowling Green, v. 60, n. 1, p. 90-103, Feb. 2011. doi: 10.1111/j.1741-3729.2010.00635.X

LIFTON, R. J.; OLSON, E. Symbolic immortality. In ROBBEN, A. C. G. M. (Ed.), Death, Mourning, and Burial: A cross-cultural reader. Malden, USA: Blackwell, 2009.

MARTIN, A. M. Exploring forgiveness: The relationship between feeling forgiven by God and self-forgiveness for an interpersonal offense. Unpublished doctoral dissertation, Case Western Reserve University, 2008.

MAUGER, P. A.; PERRY, J. E.; FREEMAN, T.; GROVE, D. C.; MCBRIDE, A. G.; MCKINNEY, K. E. The measurement of forgiveness: Preliminary research. Journal of Psychology and Christianity, Batavia, v. 11, p. 170-180, 1992.

MCCONNELL, K. M.; PARGAMENT, K. I.; ELLISON, C. G.; FLANNELLY, K. J. Examining the links between spiritual struggles and symptoms of psychopathology in a national sample. Journal of Clinical Psychology, New York v. 62, n. 12, p. 1469-1484, 2006.

MCCULLOUGH, M. E.; WILLOUGHBY, B. L. B. Religion, self-regulation, and self-control: Associations, explanations, and implications. Psychological Bulletin, Champaign, v. 135, n. 1, p. 69-93, 2009. 
MURRAY-SWANK, A.; MURRAY-SWANK. N. Spiritual and religious problems: Integrating theory and clinical practice. In PARGAMENT, K. I. (Editor-in-Chief); MAHONEY, A.; SHAFRANSKE, E. P. (Associate Eds.), APA handbook of psychology, religion, and spirituality. Washington, DC: American Psychological Association, 2013.

MURRAY-SWANK, N. A.; PARGAMENT, K. I. Solace for the soul: Evaluating a spirituallyintegrated counseling intervention for sexual abuse. Counselling and Spirituality, Ottawa, v. 27, n. 2, p. 157-174, 2008.

PALOUTZIAN, R. F. Purpose in life and value changes following conversion. Journal of Personality and Social Psychology, Washington, v. 41, p. 1153-1160, 1981.

PARGAMENT, K. I. The psychology of religion and coping. New York: Guilford, 1997.

PARGAMENT, K. I. Spiritually integrated psychotherapy: Understanding and addressing the sacred. New York: Guilford, 2007.

PARGAMENT, K. I.; DESAI, K. M.; MCCONNELL, K. M. Spirituality: A pathway to posttraumatic growth or decline? In: CALHOUN, L. G.; TEDESCHI, R. G. (Eds.). Handbook of posttraumatic growth. Mahwah, NJ: Lawrence Erlbaum, 2006. p. 121137.

PARGAMENT, K. I.; KOENIG, H. G.; PEREZ, L. M. The many methods of religious coping: Development and initial validation of the RCOPE. Journal of Clinical Psychology, New York, v. 56, n. 4, p. 519-543, 2000.

PARGAMENT, K. I.; KOENIG, H. G.; TARAKESHWAR, N.; HAHN, J. Religious struggle as a predictor of mortality among medically ill elderly patients: A two-year longitudinal study. Archives of Internal Medicine, Chicago, v. 161, n. 15, p. 1881-1885, 2001.

PARGAMENT, K. I.; SMITH, B. W.; KOENIG, H. G.; PEREZ, L. Patterns of positive and negative religious coping with major life stressors. Journal for the Scientific Study of Religion, New Haven, v. 37, n. 4, p. 710-724, 1998.

PARGAMENT, K. I; MURRAY-SWANK, N.; MAGYAR, G. M.; ANO, G. Spiritual struggle: A phenomenon of interest to psychology and religion. In MILLER, W. R.; DELANEY, H. D. (Eds.) Judeo-Christian perspectives on psychology. Washington D.C.: American Psychological Association, 2005.

PARGAMENT, K. I.; MURRAY-SWANK, N.; MAHONEY, A. Problem and solution: The spiritual dimension of clergy sexual abuse and its impact on survivors. Journal of Childhood Sexual Abuse, San Diego, v. 17, n. 3-4, 2008, p. 397-420, 2008.

PARK, C. L. Religion and meaning. In PALOUTZIAN, R. F.; PARK, C. L. (Eds.), Handbook of the psychology of religion and spirituality. New York: Guilford, 2013. 
PECK, M. S. Glimpses of the devil: A psychiatrist's personal accounts of possession, exorcism, and redemption. New York: Free Press, 2005.

PHILLIPS, R. E. III; CHENG, C. M.; PARGAMENT, K. I.; OEMIG, C.; COLVIN, S. D.; ABARR, A. N.; DUNN, M. W.; REED, A. S. Spiritual coping in American Buddhists: An exploratory study. The International Journal for the Psychology of Religion, Hillsdale, N.J., v. 19, n. 4, p. 231-243, 2009.

PHILLIPS, R. E. III; STEIN, C. H. God's will, God's punishment, or God's limitations? Religious coping strategies reported by young adults living with serious mental illness. Journal of Clinical Psychology, New York v. 63, n. 6, p. 529-540, 2007.

PIEDMONT, R. L. Does spirituality represent the sixth factor of personality? Spiritual transcendence and the Five-Factor Model. Journal of Personality, Durham v. 67, n. 6, p. 985-1013, 1999.

PIRUTINSKY, S.; ROSMARIN, D. H.; PARGAMENT K. I.; MIDLARSKY, E. Does negative religious coping accompany, precede, or follow depression among Orthodox Jews?

Journal of Affective Disorders, New York, v. 132, n. 3, p. 401-405, 2011.

PLAKUN, E. M. Psychiatry in Tibetan Buddhism: Madness and its cure seen through the lens of religious and national history. Journal of the American Academy of Psychoanalysis \& Dynamic Psychiatry, New York, NY ,v. 36, n. 3, p. 415-430, 2008.

PLANTE, T. G.; ALDRIDGE, A. Psychological patterns among Roman Catholic clergy accused of sexual misconduct. Pastoral Psychology, New York, v. 54, n. 1, p. 73-80, 2005 .

PURCELL, B. C. Spiritual terrorism: Spiritual abuse from the womb to the tomb. Bloomington, Indiana: AuthorHouse, 2008.

REKER, G. T. Meaning in life of young, middle-aged, and older adults: Factorial validity, age, and gender invariance of the Personal Meaning Index (PMI). Personality and Individual Differences, Oxford, v. 38, p. 71-85, 2005.

ROSMARIN, D. H.; PARGAMENT, K. I.; FLANNELLY, K. J. Do spiritual struggles predict poorer physical/mental health among Jews? The International Journal for the Psychology of Religion, Hillsdale, N.J., v. 19, n. 4, p. 244-258, 2009.

RYFF, C. D. Happiness is everything, or is it? Explorations on the meaning of psychological well-being. Journal of Personality and Social Psychology, Washington, v. 57, n. 6, p. 1069-1081, 1989.

SANDAGE, S.J.; MOE, S.P. Narcissism and spirituality. In CAMPBELL, W. K.; MILLER, J. (Eds.), The handbook of narcissism and narcissistic personality disorder: Theoretical approaches, empirical findings, and treatment. New York: John Wiley \& Sons, 2011. 
SCHOTTENBAUER, M. A.; RODRIGUEZ, B. F.; GLASS, C. R.; ARNKOFF, D. B. Religious coping research and contemporary personality theory: An exploration of Endler's (1997) integrative personality theory. British Journal of Social Psychology, Leicester, v. 97, n. 4, p. 499-519, 2006.

SHULTS, F. L.; SANDAGE, S. J. Transforming spirituality: Integrating theology and psychology. Grand Rapids: Baker Academic, 2006.

SLATER, C. L. Generativity versus stagnation: An elaboration of Erikson's adult stage of human development. Journal of Adult Development, Norwell, MA, v. 10, n. 1, p. 5365, 2003 .

SPERRY, L.; MILLER, L. Spirituality in clinical practice: Theory and practice of spiritually oriented psychotherapy. New York, NY: Routledge, 2011.

STARK, R. A. A taxonomy of religious experience. Journal for the Scientific Study of Religion, New Haven, v. 5, n. 1, p. 97-116, 1965.

STAUNER, N. Personal goal attainment, psychological well-being change, and meaning in life. Unpublished doctoral dissertation, University of California, Riverside, 2013. Available at: <http://escholarship.org/uc/item/3t34c68w>. Accessed on: October 10, 2014.

STAUNER, N.; EXLINE, J. J.; UZDAVINES, A.; BRADLEY, D. F. The religious and spiritual struggles of the nonreligious and nonspiritual. Presented at the Midyear Research Conference on Religion and Spirituality. Provo, Utah, 2015a, March.

STAUNER, N.; EXLINE, J. J.; WILT, J. A.; LINDBERG, M. J.; PARGAMENT, K. I. Predicting life meaning and satisfaction with religious \& spiritual struggles. Presented at the Midyear Research Conference on Religion and Spirituality. Provo, UT, 2015b, March.

STAUNER, N.; WILT, J. A.; GRUBBS, J. B.; PARGAMENT, K. I.; EXLINE, J. J. Neuroticism and stressful life events predict religious and spiritual struggles. Presented at the convention of the International Association for the Psychology of Religion, Istanbul, Turkey, 2015c, August.

TARAKESHWAR, N.; PARGAMENT, K. I.; MAHONEY, A. (2003). Initial development of a measure of religious coping among Hindus. Journal of Community Psychology, New York, v. 31, n. 6, p. 607-628, 2003.

TAYLOR, C. Z. Religious addiction: Obsession with spirituality. Pastoral Psychology, New York, v. 50, n. 4, p. 291-315, 2002.

TOUSSAINT, L. L.; WILLIAMS, D. R. National survey results for Protestant, Catholic, and nonreligious experiences of seeking forgiveness and of forgiveness of self, of others, and by God. Journal of Psychology and Christianity, Batavia, v. 27, n. 2, p. 120-130, 2008. 
TOUSSAINT, L. L.; WILLIAMS, D. R.; MUSICK, M. A.; EVERSON-ROSE, S. A. The association of forgiveness and 12-month prevalence of major depressive episode: Gender differences in a probability sample of U. S. adults. Mental Health, Religion and Culture, Abingdon, v. 11, n. 5, p. 485-500, 2008.

VAN KLINKEN, A. S. Gay rights, the devil and the end times: Public religion and the enchantment of the homosexuality debate in Zambia. Religion, London, v. 43, n. 4, p. 519-540, 2013.

WALLS, P.; WILLIAMS, R. Accounting for Irish Catholic ill health in Scotland: A qualitative exploration of some links between 'religion', class and health. Sociology of Health \& Illness, Oxford, v. 26, n. 5, p. 527-556, 2004.

WEBB, M.; STETZ, K.; HEDDEN, K. Representation of mental illness in Christian self-help bestsellers. Mental Health, Religion, \& Culture, Abingdon, v. 11, n. 7, p. 697-717, 2008.

WILSON, K. M.; HUFF, J. L. Scaling Satan. The Journal of Psychology, Philadelphia, v. 135, n. 3, p. 292-300, 2001.

WILT, J. A.; EXLINE, J. J.; GRUBBS, J. B.; PARK, C. L.; PARGAMENT, K. I. God's Role in Suffering: Theodicies, Divine Struggle, and Mental Health. Psychology of Religion and Spirituality. Washington, February 11, 2016. Advance online publication. Available at: <https://www.researchgate.net/publication/294276474_God's_Role_in_Suffering_Theo dicies_Divine_Struggle_and_Mental_Health $>$. <http://dx.doi.org/10.1037/reloooo058>. Accessed on: Feb. 12, 2016.

WOLFE, D. A.; FRANCIS, K. J.; STRAATMAN, A. L. Child abuse in religiously-affiliated institutions: Long-term impact on men's mental health. Child Abuse \& Neglect, Oxford, v. 30, n. 2, p. 205-212, 2006. 